\title{
Persons Needing Protection: A Reflection on Canada's Role
}

\author{
Edward Opoku-Dapaah
}

\begin{abstract}
This paper briefly reflects on strategies by which Canada can deal with new challenges-including fiscal constraints, phenomenal rise in the number of people needing protection, and the evolution of regional approaches to refugee protection-while at the same time promoting its own interests. The paper is organized around three interrelated questions concerning these matters.
\end{abstract}

\section{Précis}

Cet article se penche brièvement sur les stratégies utilisées par le Canada pour faire face à de nouveaux défis-notamment les compressions budgétaires, une hausse substantielle du nombre de personnes ayant besoin de protection et l'évolution des approches régionales à la protection des réfugié(e)s-tout en servant ses propres intérêts. L'article examine en particulier de trois questions en corrélation à ce dossier.

\section{How Can Canada Best Meet its Obligations with Respect to Persons Needing Protection?}

Canada intends to be significantly involved in protection of displaced persons, yet conceptual developments have not kept pace with social and political realities in this respect. Protection is a broad humanitarian principle including enjoyment of human rights and meeting primary needs. Clarification of exactly who should be "protected" is very important. Whereas granting asylum can be a very effective way to protect a refugee in flight, other protection measures-including protection of those who have yet to flee across national borders_can be just as effective.

Edward Opoku-Dapaah, PhD, is Research Fellow, Centre for Refugee Studies, York University, Toronto.
Displacement of people is caused by gross violations of human rights and immense suffering throughout the world and will need to be addressed with the full range of economic, political, diplomatic and developmental responses available to the government. Some displacements may be avoided if preemptive actions are taken to resolve life-threatening conflicts; others may be amenable to development planning or may be handled through substantial assistance to countries of first asylum and regional settlement. To some analysts protection should spring from objective conditions, where the facts indicate the risk of harm for valid reasons including war, violence, conflict and massive violations of human rights (Goodwin-Gill 1995, 7; ECRE 1991). Whether Canada can fulfil such responsibility without institutional resources, such as a pool of prominent jurists and legal scholars, is questionable.

Like that of many other Western nations, Canada's obligation to refugees has been stretched by its efforts to respond to the proliferation of conflicts around the globe. The need to "define" a precise but important role within overall international efforts hovers pervasively. Adelman and Cox (1994, 266) argue that the difficulties in coping with the thousands of refugees that were displaced by the Gulf War made clear the need for greater coordination in the responses of the various UN agencies to the displacement of persons. Yet, to a large extent, coordination of available international responses and relief efforts remains unrealized. Efforts to develop a coordinating mechanism may be contingent upon effective administration, generosity in spirit and finance, and a more proactive policy (ibid.).

Mounting evidence clearly suggests that procedures designed to deflect asylum seekers from one's country to other countries are both more costly and less effective than multilateral efforts. They are more costly because a great deal of expenditure must be directed at preventing asylum seekers from reaching one's shores through measures such as issuing of visas, and carrier costs to check for improper documents (Adelman 1994, 87). A review of practices in Western Europe since the 1980s suggests that stringent measures, such as detention, designated accommodation, employment restrictions, summary process, removals, carrier sanctions, and restrictive interpretations of asylum criteria, can only exercise temporary influence on the inflow of asylum seekers (Goodwin-Gill 1993, 383; ECRE 1991, 115).

Even though the magnitude of global refugee crises necessitate joint responsibility and cooperation in achieving solutions, some regional accords covering refugees provide only a limited degree of protection for those involved. Hathaway $(1992,80$ ) argues that the Schengen accord, for instance, does not institute community monitoring of clearly defined procedural standards for status determination, much less mandate fair-minded interpretations of the UN Convention's refugee definition. Moreover, the harmonization agreements give some states an incentive to offer only the lowest common denominator in terms of protection. Commenting about the "safe third country" provision, Adelman $(1994,75)$ notes that this provision prevents movement to a secondary country of asylum even if there are reasons for movements, such as restrictive asylum practices in the first country of asylum relative to others, or the existence of refugee networks that can provide assistance in one jurisdiction but which are unavailable in another. Thus the "safe third country" clause has become one of the most 
serious obstacles to an effective solution of the world's refugee problem, since it generalises the most restrictive community practices, thereby eroding the rights of asylum seekers (Melander 1992, 102).

To many refugee researchers protection of displaced persons around the globe requires a coherent system of solutions, rather than multiple, national and unilateral responses which are incoherent and inconsistent. For example, multilateral conventions such as the "safe third country" provision could better promote refugee protection if they were explicitly designed to allocate responsibilities among nations (Adelman 1994, 88). Furthermore, such agreements should provide that a refugee claimant is the responsibility of the country where the claimant first lands, and that countries would share the costs of refugee protection so that if one country receives only a few claimants it would assist those countries which receive more with the associated costs (ibid.). The objective of such an agreement should not only be to secure practical working arrangements between states, but also to clarify the responsibilities of international agencies and their new role in a changed political situation (Goodwin-Gill 1993, 385).

Canada has come a long way with respect to its international obligations towards refugees, yet it is evident that efforts by Canadian governments to confront public hostility to large-scale movement of refugees into this country remains weak (Abella 1993, 93; Angus Reid 1989). As well, despite the fact that some changes have occurred and a more gender-sensitive approach to refugee questions has become noticeable, much still needs to be done to identify key refugee women's issues and to propose adequate responses (Moussa 1993).

\section{What Level of Resources Should \\ Canada Devote to Persons in Need of Protection?}

It is extremely difficult to determine precisely what level of resources should be devoted towards protecting refugees and displaced persons. Recent experience indicates a general need for assistance in all aspects of management and response. There is the need for a permanent or regular funding base sufficient to allow strategic planning and effective response.

By accepting refugees on humanitarian grounds, Canada's settlement policy is based on the assumption that they do not have the same qualifications and skills as independent or economic immigrants (Neuwirth 1994, 315). If refugees are unable to secure or are prohibited from seeking employment in order to sustain themselves, then their basic needs must be met through public assistance (Lanphier and Opoku-Dapaah 1997, 9). Moreover, states are not only obliged to equate resident refugees with nationals in the operation of all forms of public assistance, but also must not discriminate among and between refugee populations in the granting of relief, whatever the number of refugees or the limitation of resources (Hathaway and Dent 1995, 30).

According to some researchers, nations should collectively seek the most efficacious method for dealing with refugee protection. Adelman $(1994,86)$ has argued that it would be far more cost effective if the sixteen Western countries adjudicating asylum claims had a common system. At minimum, a common documentation centre for all asylum adjudication countries would eliminate duplication in preparing country profiles (ibid.). For GoodwinGill $(1993,386)$, joint efforts in information and counselling for those who do seek protection as refugees may indirectly enhance the capacity of systems to deal with demands for refugee status. Mandates need to be clearly explained, just as national institutional arrangements, including local nongovernmental organizations, must be strengthened, both to ensure effective cooperation with relevant agencies, and to implement appropriate policies, standards and decisions (ibid.).

While the immediate needs of refugees may be met to some degree within the first year after arrival, due to many arrangements in place for newcomers, in reality, the period of adjustment is far more protracted (Lanphier 1994, 5). McLellan $(1995,2)$ discovered that the extensive traumatic experiences of Cambodian refugees prior to arrival in Canada had residual effects which prolonged and increased their need for specialized settlement services. Yet, government and social service programs were mainly available for only the first year after arrival. Given these inadequacies, the need of Cambodians for settlement services-including translation, interpretation, documentation and escort services-has not noticeably diminished even ten years after their arrival in Canada (ibid.). Life history studies of newcomers have consistently demonstrated the continuous and arduous nature of adaptation to Western lifestyles, even among those whose backgrounds attest to their unusual resilience (Moussa 1993).

Available evidence indicates that expenditure on asylum seekers going through the inland refugee determination process is substantial. By all projection, the inflow of asylum seekers is likely to remain a continuous problem for Canada. Yet still, the level of resources and institutional means for serving these people are lacking (Lanphier and Opoku-Dapaah 1997). This issue is examined further below.

\section{What is the Most Effective Way to Provide Fair Determination of Refugee Status in Canada?}

Efficient and expeditious procedures are the key to a successful refugee determination process. Yet, some claimants in Toronto still experience delays of up to three years before completing the inland determination process (Opoku-Dapaah 1997). A recent study of Ghanaian refugees revealed that a combination of factors including prearrival trauma, sparse entitlements and protracted delays in obtaining legal status, encourages passivity and financial dependency (ibid.). ECRE $(1991,117)$ maintains that cases where the decision about a refugee claim is not reached within a year from the date of application, the asylum seeker 
should be granted a temporary residence permit, unless the responsibility for the delay lies entirely with the applicant. However, measures intended to shorten procedures should not lead to lowering of legal safeguards; on the other hand, procedures offering a complex range of legal interventions should not be considered inefficient.

In a 1993 report prepared for the IRB, Hathaway $(1993,76)$ argues that claims should be reviewed by a geographically specialized officer, and if the officer is satisfied that the claim can be accepted without a full hearing, a recommendation to that effect should be made to relevant authorities. In addition, the Chairperson should prepare and issue guidelines on the assessment of credibility (ibid.).

Immigration officials posted at ports and other border officers deal with asylum seekers, yet it is unclear whether these officials are kept regularly informed about developments in this field, or whether they possess the special training relating to problems posed by asylum seekers, especially women and children.

Given that refugee counsel are typically schooled in the adversarial procedure, they present proof through the detailed examination of claimant and witnesses. By contrast, Glenn (1994, 109) notes that a more investigative procedure should place no burden of proof on the refugee claimant, while the role of counsel should become one of collaboration rather than struggle. Consequently, the determination process could be expedited through a more collaborative and investigative procedure in which questioning is undertaken by CRDD members themselves rather than by refugee counsel and RHOs, while existing procedural guarantees of the right to counsel and legal aid would be retained (Cox and Glenn 1994, 298). For example, CRDD members rely on model reasons provided by the IRB for denial of claims from certain countries; this practice may be unfair and also undermines the independence of the CRDD members from executive influence (ibid.).
Another area of concern is the authority and credibility of documentary evidence in refugee hearings, particularly information assembled by the IRB's Documentation Centres. Although refugee claimants are given an effective opportunity to refute adverse information used against them during refugee hearings, in practice Board Members give greater probative value to documentary evidence (often produced by the IRB's Documentation Centre) than to the claimant's testimony (Houle 1994, 28). Board members often fail to weigh all the evidence in front of them or chose to ignore some of the testimony (ibid.). For Houle, because no criteria (other than those generally used by regular libraries) have ever been laid down for the acquisition of material by the Resource Centre, little is known about the sources used in its production of documents. This is problematic, considering that the Documentation Centre provides information to Board Members upon which important decisions are based.

Although the post-1989 refugee-determination procedure does provide all refugee claimants with an oral hearing, the legislation overlooks the importance of a reasonable and fair access to appeal (Greene and Shaffer 1992, 82). Procedures which necessarily limit appeals and judicial reviews violate the guarantee of fundamental justice given by the Canadian Charter of Rights and Freedoms, and the guarantee of a fair hearing given by the Canadian Bill of Rights.

In sum, in the absence of durable solutions for the root causes of displacement, it is imperative that Canada continue its tradition of generosity and compassion towards refugees. A coherent strategy for meeting such an obligations calls for a well coordinated international approach, burden sharing, and clarification of Canada's precise role within multilateral efforts. With respect to asylum seekers, experience suggests that sophisticated ways of controlling frontiers do not adequately address the complexities of the issue. A fair asylum determination procedure should be coherent, corroborative and placed in the hands of qualified officials who can conduct hearings in an efficient manner.

\section{References}

Abella, I. 1993. “Canadian Refugee Policy to 1980." In The International Refugee Crisis: British and Canadian Responses, edited by V. Robinson, 77-94. Houndmills, UK: Macmillan Press.

Adelman, H. 1994. "The Safe Third Country in Canadian Legislation." European Journal of International Migration and Ethnic Relations, no. 21 and 22, 71-94.

Adelman, H., and D. Cox. 1994. "Overseas Refugee Policy." In Immigration and Refugee Policy: Australia and Canada Compared, edited by $\mathrm{H}$. Adelman et al., 255-82. Victoria: Melbourne University Press, and Toronto: University of Toronto Press.

Angus Reid Associates. 1989. Attitudes and Perceptions of Selected Dimensions of Refugee and Immigration Policy in Canada. Final Report to Employment and Immigration Canada.

ECRE. 1991. "Fair and Efficient Procedures for Determining Refugee Status." International Journal of Refugee Law 3 no. 1,11219.

Glenn, P. 1994. "Procedural Rights of Refugee Claimants." European Journal of International Migration and Ethnic Relations, no. 21 and 22, 95-110.

Cox, D., and P. Glenn. 1994. "Illegal Immigration and Refugee Claims." In Immigration and Refugee Policy: Australia and Canada Compared, edited by $\mathbf{H}$. Adelman et al. 283-308. Victoria: Melbourne University Press, and Toronto: University of Toronto Press.

Goodwin-Gill, G. 1995. "Asylum: The Law and Politics of Change." International Journal of Refugees 7, no. 1.

Goodwin-Gill, G. 1993. "Towards a Comprehensive Regional Policy Approach." International Journal of Refugees 5, no. 3 , 347-91.

Greene, I., and P. Shaffer. 1992. "Leave to Appeal and Leave to Commence Judicial Review in Canada's Refugee Determination System: Is the Process Fair?" International Journal of Refugee Law 4, no. 1, 57-71.

Hathaway, J. C. 1993. Rebuilding Trust. North York: Osgoode Law School, York University.

Hathaway, J. C., and J. A. Dent. 1995. Refugee Rights: Report on Comparative Survey. Toronto: York Lanes Press. 